\title{
Experimental investigation and development of correlations for pongamia pinnata biodiesel
}

\author{
Siraj Sayyed ${ }^{1,2}, R K \operatorname{Das}^{1}$, and Kishor Kulkarni ${ }^{2, *}$ \\ ${ }^{1}$ Department of Mechanical Engineering, Indian Institute of Technology (ISM), Dhanbad-826004 \\ $(\mathrm{JH})$, India \\ ${ }^{2}$ Department of Mechanical Engineering, Maharashtra Institute of Technology, Aurangabad-431010 \\ (MS), India
}

\begin{abstract}
Most promising alternative source available for fossil diesel in India is the Pongamia pinnata biodiesel (Karanja biodiesel in the Indian context). The characterization of biodiesel plays an important role in engine emission and performance. Due to oxygenation the biodiesel has low higher heating value than fossil diesel hence it is necessary to study the effect of different physio-chemical properties on higher heating value. Experimentations were conducted on 11 samples on the basis of Volume \% for Pongamia Pinnata biodiesel and diesel blends in the step of 10 varying from $0 \%$ (Fossil diesel) to $100 \%$ (Pongamia pinnata biodiesel). A retrospective investigation is conducted for characterization of biodiesels and different physio-chemical properties are correlated as a function of Higher Heating Value (HHV). By the traditional statistical technique of regression analysis the correlations can predict the HHV values with the accuracy of $\mathrm{R}^{2}=0.9907$ and uncertainty of $\pm 6.19 \%$. HHVs obtained by performing experiments and by predicted correlations are compared with the correlations available in open literature. The study reveals that the properties of kinematic viscosity and density have a strong correlation with $\mathrm{HHV}$ as compared to cetane number and flash point.
\end{abstract}

\section{Introduction and Literature Review}

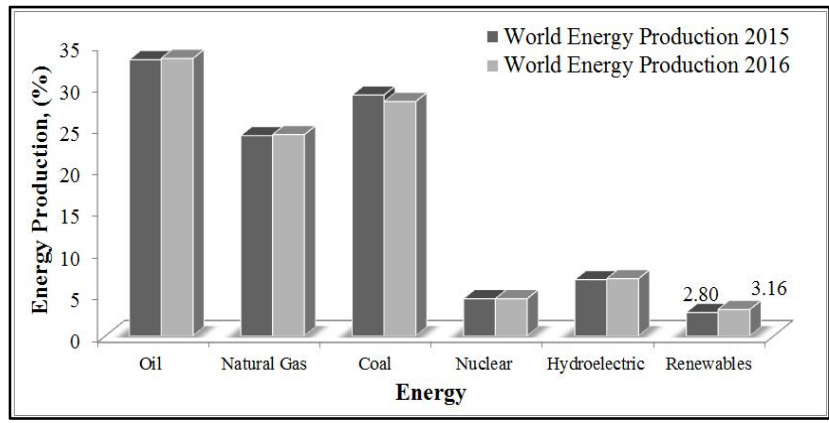

Fig. 1. Energy Types versus Energy Production.

\footnotetext{
* Corresponding author: kkenergy@gmail.com
} 
The important issue confronting at the global level is energy crises [1]. However fossil fuels have numerous of applications including sub-marines, locomotives, transportations, and industrial sectors etc. The emissions produced by these fossil fuels are unsafe to the environment and human beings in particular [2]. There are various kinds of energy resources available in the nature but the fossil fuels contribute more than $80 \%$ of the world energy requirement. Fossil fuels reservoirs are depleting very rapidly throughout the world [3]. Therefore renewable energy sources are one of the alternatives available in place of fossil fuels. According to Petroleum Planning and Analysis Cell the consumption of diesel fuel in India and its equivalent $\mathrm{CO}_{2}$ liberation for the year 2016-2017 was 196.48 million tons and 2454.97 million tons respectively. Figure 1 show the type of energies and production information worldwide for the year 2015 and 2016 and it is found that oil is the major contributor of energy production followed by coal and natural gas. Hence future energy demands can be fulfilled by biodiesel. Table 1 shows the specification of biodiesels $[4],[5]$.

Table 1. Specification of biodiesels.

\begin{tabular}{|l|l|}
\hline Common Name & Biodiesel \\
\hline Common Chemical Name & Fatty Acid Methyl Ester \\
\hline Chemical Formula Range & $\mathrm{C}_{14}-\mathrm{C}_{22}$ Methyl Esters or $\mathrm{C}_{15-25} \mathrm{H}_{28}-48 \mathrm{O}_{2}$ \\
\hline Kinematic Viscosity Range $\left(\mathrm{mm}^{2} / \mathrm{s}\right.$ at $\left.40^{\circ} \mathrm{C}\right)$ & $1.9-6.0$ as per ASTM and $3.5-5.0$ as per \\
& EN \\
\hline Density Range $\left(\mathrm{kg} / \mathrm{m}^{3}\right.$ at $\left.15^{\circ} \mathrm{C}\right)$ & $860-900$ \\
\hline Boiling Point $\left({ }^{\circ} \mathrm{C}\right)$ & $>202$ \\
\hline Flash Point Range $\left({ }^{\circ} \mathrm{C}\right)$ & $147-177$ \\
\hline Distillation Range $\left({ }^{\circ} \mathrm{C}\right)$ & $197-327$ \\
\hline Vapour Pressure $\left(\mathrm{mm}\right.$ of $\mathrm{Hg}$ at $\left.22^{\circ} \mathrm{C}\right)$ & $<5$ \\
\hline Solubility in Water & Insoluble in Water \\
\hline Physical Appearance & Light to Dark Yellow, Clear Liquid \\
\hline Odour & Light Musty, Soapy Odour \\
\hline Biodegradability & More Biodegradable than Fossil Diesel \\
\hline Reactivity & Stable, but avoid oxidizing agents \\
\hline
\end{tabular}

Biodiesel can be produced from edible, non-edible oils and it can be blended with fossil diesel in four different ways named as direct use / blending, micro-emulsion, pyrolysis, and transesterification [6]. Biodiesel can be manufactured by transesterification processes and esterification process followed by transesterification. Utilization of biodiesel and their blends in $\mathrm{CI}$ engines aids in the reduction of unburned $\mathrm{HC}, \mathrm{CO}$, and PM. The edible-oils are not suitable for biodiesel production in any developing countries of the world due to food security [7], [8]. Whereas in India the non-edible tree born seeds like pongamia pinnata, Jatropha Carcus, Mellia Azadirachta, and Madhuca Indica are being considered as potential source for biodiesel production [9]. This non-edible oil give 30 to $40 \%$ oils from their seeds, fruits, nuts and the kernels. The pongamia seed contain about $40 \%$ oil, which can be converted to biodiesel by transesterification method. Pongamia biofuel requires no engine modifications, when blended with diesel in proportions as high as $20 \%$ [10].

Agarwal and Rajamanoharan (2009) used karanja biodiesel blends $(0 \%, 10 \%, 20 \%$, $50 \%, 75 \%$, and $100 \%$ ) with and without preheating of biodiesel in Kirloskar make AV-1 agricultural diesel engine. They conclude that no modification required in engine hardware for without preheating karanja biodiesel and their blends. However, while using preheated karanja biodiesel blends in an IC engine the efficiency of the engine is improved slightly as compared to without preheating karanja biodiesel blends. The thermal efficiency of the preheated oil blends is nearly $30 \%$ and without preheated is in the range of 24 to $27 \%$. Davies and Hussain (2010) used plant oil as fuels for compression ignition engines and compared different biodiesel blends and its effect on engine performance and emissions. 
The study revealed that applications of preheated $\left(60^{\circ} \mathrm{C}\right)$ pongamia biodiesel blends $(0: 100$, $50: 50,75: 25,100: 0)$ in USHA make $2.6 \mathrm{~kW}$ single cylinder air-cooled engine. Reduce power by $2.9 \%$ for $100 \%$ pongamia oil. BSFC/BSEC increased for pongamia oil than diesel due to self-oxygenation, unsaturation, and bulk modulus. Brake thermal and mechanical efficiency decreases as the pongamia oil \% increases and it is lowest for pure pongamia oil. It has been observed that as pongamia oil blended with diesel and preheated to $60^{\circ} \mathrm{C}$ before blending, the valves clogged within $70 \mathrm{~h}$ of engine operations. Agarwal and Rajamanoharan (2009), Davies and Hussain (2010), Rao (2011), Bobade and Khyade (2012), Bello and Otu (2012), and Evangelos (2013) studied the following properties density, viscosity, flash point, fire point, cetane number, cetane number, heating values, iodine values, and acid values of pongamia biodiesel and their blends for engine emissions and performance. Alptekin and Canakci (2008) studied density and viscosity for different biodiesels and diesel. They have developed the correlations for density and viscosity from the mass fraction and biodiesel fractions. Similar study is performed by Mishra et al. (2010) for development of correlation based on temperature, blend proportions, mass fractions, and biodiesel fractions. Sivaramakrishnan (2011) studied different physio-chemical properties like density, kinematic viscosity, flash point, and cetane number as a function of higher heating value for different biodiesels. Sivaramakrishnan and Ravikumar (2012) studied the cetane number and its influence on physical properties of biodiesel like flash point, fire point, calorific value, viscosity, and cetane number for different biodiesels blends and developed correlations for the same.

The measurement of physio-chemical properties and its effect on engine performance and emissions are studied in open literature. Density increases with the decrease in chain length and with unsaturation of hydrocarbon [6]. Density can impact on fuel consumption as fuel introduced into the combustion chamber is determined by volumetrically. Biodiesel fuels are having higher density than fossil diesel, which means that volumetrically operating fuel pumps will inject greater mass of biodiesel than fossil diesel fuel [7]. Since the flow is controlled by volume, the expected peak power for engines when using B100 as fuel is only 5 to $7 \%$ less than that of the fossil diesel because more fuel $(\mathrm{g} / \mathrm{ml})$ would flow and vaporize more efficiently given a set throttle (volume) [11]. The average density of biodiesel is approximately 10 to $12 \%$ higher than the density of fossil diesel. Actually, it has been argued that there exists a correlation between density and NOx emissions, with lower densities favouring lower NOx, although other researchers have not confirmed such an unequivocal trend [8]. The viscosity ranges are different according to different test methods. The viscosity of the biodiesel decreases exponentially with increase in temperature [6]. Several structural features influence the kinematic viscosities of FAME, such as chain length, degree of unsaturation, double bond orientation, and type of ester head group. Factors such as longer chain length and larger ester head group result in increases in kinematic viscosity. Increasing the degree of unsaturation results in a decrease in kinematic viscosity and as the temperature of oil is increased its viscosity decreases enabling it to flow more readily. Double bond orientation also impacts the kinematic viscosity [12]. Flash point varies inversely with the fuels volatility. Thus, biodiesel is safer to handle at higher temperature than fossil diesel. The flash point of non - edible oils is much higher than that of fossil diesels. As the impurities increases in the biodiesel and diesel blends ultimately the flash point also increases. Flash point temperature indicates the overall flammability hazard in the presence of air, higher flash point makes for safe handling and storage [13]. One of the most influential properties of the diesel fuel is the dimensionless cetane number $(\mathrm{CN})$, which represents the ignitability of the fuel, particularly critical during cold starting conditions. The cetane number of the fuel is one such important parameter which is responsible for the delay period. Higher the cetane number, shorter the ignition delay time and vice versa. The cetane number assists in the smooth combustion with lower knocking 
characteristics in the diesel engine. Cetane number decreases as the number of double bonds in the chain (or the unsaturation) increases. Biodiesel has a higher cetane number because of its higher oxygen content [14]. Biodiesel contains on average 10-12\% w/w oxygen, which leads to proportionally lower energy density and heating value, thus more fuel needs to be injected in order to achieve the same engine power output. Increasing the unsaturation or the number of double bonds, results in a moderate increase in heating value of FAME. Higher the oxygen content, lower the heating value, and higher the potential for particulate reduction [15]. Due to higher oxygen content of the biodiesel that produces more complete combustion of the fuel and soot. On the other hand, the fact that greater mass of biodiesel needs to be injected in order to achieve the same engine power as with conventional diesel fuel is responsible for increase oxides of nitrogen in emissions. B100 has lower energy content than the diesel fuel by $11 \%$ approximately [4], [13].

\section{Experimentation}

In the characterization of biodiesels the density, kinematic viscosity, flash point and cetane number are undertaken in prediction of the higher heating values. The density of the pongamia pinnata biodiesel blends measured by the hydrometer according to ASTM D941 standards and the kinematic viscosity was determined at $40^{\circ} \mathrm{C}$ by multiplying the constant of viscometer tube and the measured efflux time, which is the time for a known volume of liquid flowing under gravity to pass through a calibrated glass capillary viscometer tube. The flash point measured by pensky marten closed cup apparatus according to ASTM D93 standard and the cetane number measured by ignition quality tester according to ASTM D613 standard. At last the higher heating values were measured by the apparatus of Bomb calorimeter according to ASTM D240 standard. The preliminary experimentation by using these blends has been carried out on Kirloskar make IC engine to evaluate the performance and emission parameters. Table 2 shows the information of measurement test methods and the uncertainty present in the measurement.

Table 2. Measuring instruments and uncertainty analysis.

\begin{tabular}{|l|c|c|l|c|}
\hline $\begin{array}{c}\text { Physio-chemical } \\
\text { Property }\end{array}$ & Units & $\begin{array}{c}\text { Method of } \\
\text { Analysis }\end{array}$ & \multicolumn{1}{|c|}{ Instrument Used } & $\begin{array}{c}\% \\
\text { Uncertainty }\end{array}$ \\
\hline Density, $(\rho)$ & $\mathrm{kg} / \mathrm{m}^{3}$ & ASTM D941 & Hydrometer & 1.003 \\
\hline $\begin{array}{l}\text { Kinematic } \\
\text { Viscosity, }(v)\end{array}$ & $\mathrm{mm}^{2} / \mathrm{s}$ & ASTM D445 & $\begin{array}{l}\text { Kinematic Viscometer Bath } \\
\text { tub }\end{array}$ & 5.220 \\
\hline Flash Point, (F) & ${ }^{\circ} \mathrm{C}$ & ASTM D93 & $\begin{array}{l}\text { Pensky Marten Closed Cup } \\
\text { Apparatus }\end{array}$ & 1.000 \\
\hline $\begin{array}{l}\text { Cetane Number, } \\
\text { (CN) }\end{array}$ & No. & ASTM D613 & Ignition Quality Tester & 3.000 \\
\hline $\begin{array}{l}\text { Higher Heating } \\
\text { Value, (HHV) }\end{array}$ & $\mathrm{MJ} / \mathrm{kg}$ & ASTM D240 & Bomb Calorimeter & - \\
\hline
\end{tabular}

Figure 2 shows the different physio-chemical properties and its percentage variations from neat diesel fuel for different blends of pongamia pinnata biodiesel. Density of pongamia pinnata biodiesel is $8.798 \%$ more than by the neat diesel fuel and subsequently kinematic viscosity, flash point of pongamia pinnata biodiesel are $276.923 \%$ and 182.692 $\%$ more than by neat diesel fuel. But the cetane number and higher heating values of pongamia pinnata biodiesel are $7.959 \%$ and $15.525 \%$ fewer than by the neat diesel fuel. Trend is not linear in kinematic viscosity and flash points and its reason already seen in the literature review in the section of kinematic viscosity and flash point. 


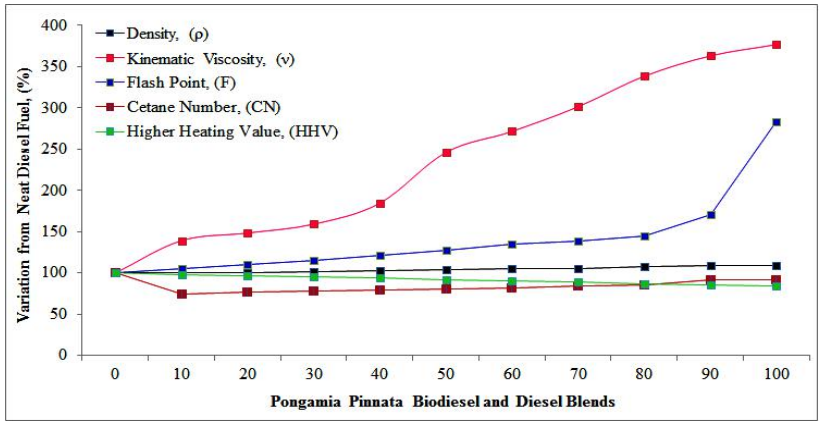

Fig. 2. Blends versus \% Variations in Physio-chemical Properties.

\section{Results and Discussion}

Numerous authors have correlated the various physio-chemical properties like density, kinematic viscosity, flash point as a function to the cetane number and higher heating values by the least square approximation. The physio-chemical properties of fuels are correlated with other properties for establishing correlations of density, kinematic viscosity, flash point, cetane number and higher heating value. Following correlations were developed through the regression analysis to predict the Estimated HHV.

$$
\begin{gathered}
H H V_{E s t}=112.047-0.0854331 \times \rho \\
H H V_{E s t}=45.8031-0.5995 \times v \\
H H V_{E s t}=45.2092-0.0663784 \times F \\
H H V_{E s t}=46.3868-0.147154 \times C N \\
H H V_{E s t}=70.3942-0.0316867 \times \rho-0.379483 \times v \\
H H V_{E s t}=65.8485-0.025724 \times \rho-0.402125 \times v-0.00344598 \times F
\end{gathered}
$$

$H H V_{E s t}=92.0444-0.0623755 \times \rho-0.156786 \times v-0.00485384 \times F+0.0592909 \times C N(7)$

Figure 3 shows the HHV of pongamia pinnata biodiesel and diesel blends versus actual higher heating values. The HHV predicted through the individual physio-chemical properties correlations from flash point and cetane number that are having very less accuracy of prediction i.e. $\mathrm{R}^{2}=0.61$ to 0.98 . But in other cases HHV predicted through individual physio-chemical properties correlations from density, kinematic viscosity shown strong correlation with HHV i.e. $\mathrm{R}^{2}=0.98$ to 0.99 . Apart from these, the combined physiochemical properties correlations have shown very high degree of accuracy in prediction of HHV from all considered physio-chemical properties i.e. $\mathrm{R}^{2}=0.9907$. So, the study reveals that the properties of kinematic viscosity and density have a strong correlation with HHV as compared to cetane number and flash point. Figure 4 gives the information of pongamia pinnata biodiesel blends and the \% variation of HHV from the base HHV. In this diagram the base values considered as the experimental values of HHV and compared with predicted values from correlations. Correlation 1 has given the \% variations in the ranges from -1 to +2 and subsequently $2,3,4,5,6$, and 7 has been given the $\%$ variations in the ranges from 1 to $+1,-5$ to $+5,-7$ to $+11,-1$ to $+1,-1$ to +1 , and -1 to +1 . So from the graph it has been clearly seen that the final correlation i.e. Correlation of HHV from $\rho, v, F$, and $\mathrm{CN}$ has shown strong correlation between experimental HHV and Estimated HHV. Finally the HHV predicted by open literature correlation model and our developed correlation model compared with the available blends in open literature correlation model. Equation 8 gives the information of correlation model available in open literature which predicts HHV from 
$\rho, v$, and F. We have also developed same physio-chemical properties correlation model which is given in equation No.6.

$$
H H V=0.4527 \times v-0.0008 \times \rho-0.0003 \times F+40.3667
$$

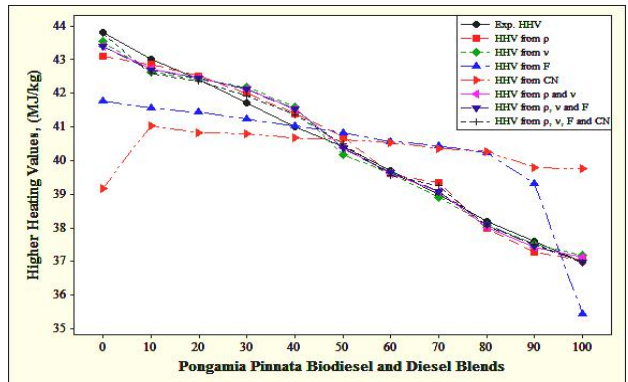

Fig. 3. Blends versus Higher Heating Values.

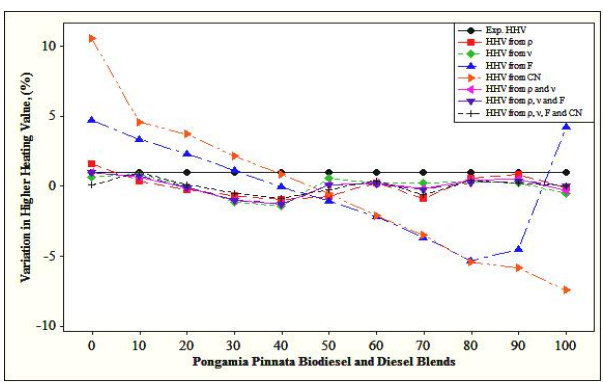

Fig. 4. Blends versus \% Variation in Higher Heating Values.

After the comparison of available pongamia biodiesel and diesel blends and experimental HHV, estimated HHV by correlation 6 and 8 given in Figure 5. It has been seen that the correlation 6 has given better results than the correlation 8 which was available in open literature.

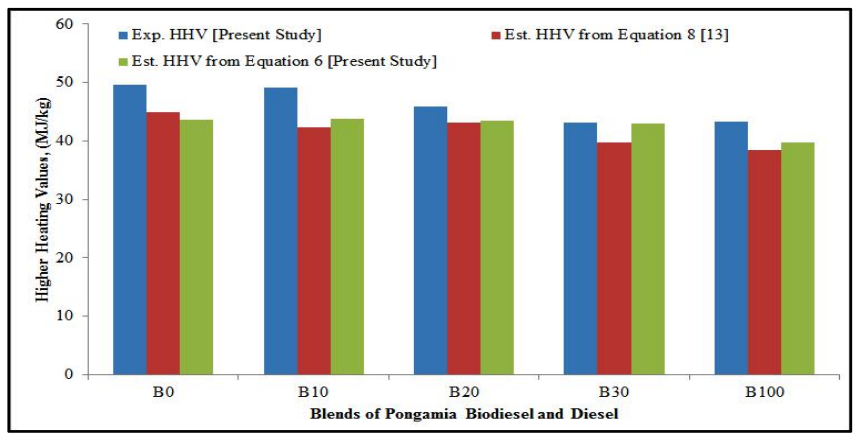

Fig. 5. Validation and comparison of correlation model with open literature.

\section{Conclusions}

It is established that the physical and chemical properties of biodiesel fuels have predominant effect on higher heating values on the blends of pongamia pinnata and diesel.

1. The values of density, kinematic viscosity, and flash point of biodiesel blends increases as the percentage of biodiesel increases in the blends due to the higher values of biodiesel than that of fossil diesel.

2. Cetane number increases with increases moderately with increase of the biodiesel concentration.

3. The higher heating values of the blends decrease with increase of pongamia pinnata biodiesel increase which is attributed due to the oxygenated structure of biodiesel.

4. If two, three and four physio-chemical properties are considered for modelling correlation the accuracy of $\mathrm{HHV}$ prediction ranges respectively from $61.00 \%$ to $98.00 \%, 98.00 \%$ to $99.00 \%$ and 99.00 to $99.07 \%$.

5. The most and the least accurate values for HHV predicted by correlation 7 and 4 and the variations observed in it that are in the range of -1 to +1 and -7 to +11 .

6. Preliminary experimental study requires understanding the effect of different 
physio-chemical properties of assorted biodiesel and diesel blends.

\section{Acknowledgement}

The authors wish to acknowledge the Green Fuel Laboratory, Chemistry Laboratory, Shimadzu Laboratory of MIT Aurangabad (MS), SVM Agro Processor, Nagpur (MS) and Indian Biodiesel Corporation Baramati, Pune (MS) for providing the required support to carry out the experimentation of characterization of biodiesel and its blends.

\section{References}

1. D. Huang, H. Zhou, and L. Lin, "Energy Procedia Biodiesel: an Alternative to Conventional Fuel," 2012.

2. A. Demirbas, "Progress and recent trends in biodiesel fuels," Energy Convers. Manag., vol. 50, no. 1, pp. 14-34, 2009.

3. B. Tesfa, R. Mishra, F. Gu, and N. Powles, "Prediction models for density and viscosity of biodiesel and their effects on fuel supply system in CI engines," Renew. Energy, vol. 35, no. 12, pp. 2752-2760, 2010.

4. S. Siraj and H. M. Dharmadhikari, "Performance and Emission Characteristics of Diesel Engine Fuelled with Biodiesel and its Blends: A Review," vol. 2, no. 10, pp. 3235-3243, 2013.

5. H. M. Dharmadhikari, P. R. Kumar, and S. S. Rao, "PERFORMANCE AND EMISSIONS OF C . I . ENGINE USING BLENDS OF BIODIESEL AND DIESEL AT DIFFERENT INJECTION PRESSURES,” pp. 1-6, 2012.

6. B. R. Moser, "Biodiesel production, properties , and feedstocks," pp. 229-266, 2009.

7. A. K. Agarwal, "Biofuels ( alcohols and biodiesel ) applications as fuels for internal combustion engines," vol. 33, pp. 233-271, 2007.

8. A. K. Agarwal and K. Rajamanoharan, "Experimental investigations of performance and emissions of Karanja oil and its blends in a single cylinder agricultural diesel engine," vol. 86, pp. 106-112, 2009.

9. S. N. Bobade and V. B. Khyade, "Detail study on the Properties of Pongamia Pinnata ( Karanja ) for the Production of Biofuel,” vol. 2, no. 7, pp. 16-20, 2012.

10. V. Kesari and L. Rangan, "Development of Pongamia pinnata as an alternative biofuel crop - current status and scope of plantations in India," J. Crop Sci. Biotechnol., vol. 13, no. 3, pp. 127-137, 2010.

11. L. Lin, Z. Cunshan, S. Vittayapadung, S. Xiangqian, and D. Mingdong, "Opportunities and challenges for biodiesel fuel," Appl. Energy, vol. 88, no. 4, pp. 1020-1031, 2011.

12. E. Alptekin and M. Canakci, "Determination of the density and the viscosities of biodiesel-diesel fuel blends," Renew. Energy, vol. 33, no. 12, pp. 2623-2630, 2008.

13. K. Sivaramakrishnan and P. Ravikumar, "PERFORMANCE OPTIMIZATION OF KARANJA BIODIESEL ENGINE,” vol. 7, no. 4, pp. 506-516, 2012.

14. K. Sivaramakrishnan and P. Ravikumar, "DETERMINATION OF CETANE NUMBER OF BIODIESEL AND IT ' S INFLUENCE ON PHYSICAL PROPERTIES," vol. 7, no. 2, pp. 205-211, 2012.

15. P. V Rao, "Effect of properties of Karanja methyl ester on combustion and NOx emissions of a diesel engine," J. Pet. Technol. Altern. Fuels, vol. 2, no. May, pp. 63-75, 2011. 


\section{Nomenclature}

\begin{tabular}{|c|c|c|c|}
\hline Abbreviation & Description & Abbreviation & Description \\
\hline$\rho$ & Density & $\mathrm{B}$ & Biodiesel and Diesel Blends \\
\hline$v$ & Kinematic Viscosity & KOME & Karanja oil methyl ester \\
\hline $\mathrm{F}$ & Flash Point & $\mathrm{HHV}_{\text {Est. }}$ & Estimated HHV \\
\hline $\mathrm{CN}$ & Cetane Number & HHV & Higher Heating Value \\
\hline$\%$ & Percentage & ASTM & $\begin{array}{l}\text { American Society for Testing and } \\
\text { Materials }\end{array}$ \\
\hline
\end{tabular}

